\title{
Cavitation Control as a Means of Reducing Algal Biomass in Pond Waters
}

\author{
ZEN'ICHIRO KAWABATA ${ }^{1 *}$, PATHMALAL MARAKKAL MANAGE ${ }^{2}$, YASUYUKI MIYAI ${ }^{3}$, \\ MAKOTO HISAMOTO ${ }^{3}$, and MASAHIRO MIYAI ${ }^{3}$ \\ ${ }^{1}$ Center for Ecological Research, Kyoto University \\ / Kamitanakami Hirano-cho 509-3, Otsu 520-2113, Japan \\ ${ }^{2}$ Department of Zoology, University of Sri Jayewardenapura / Nugegoda, Sri Lanka \\ ${ }^{3}$ Daiwa-kiko Ltd. / Oyabucho-kamayaura 1777, Sakaide 762-0015, Japan
}

\begin{abstract}
This is a first report of the use of cavitation treatment, an innovative method, to suppress phytoplankton biomass. It was found that cavitation treatment immediately killed some algal cells in pond waters; about $75 \%$ of Peridinium sp. died when exposed to cavitation for one minute at $1800 \mathrm{rpm}$ of the shaft rotation in a cylinder. The effectiveness of cavitation for causing algal death varied with different species. These results showed the possibility of using cavitation treatment to suppress algal biomass for a short time. Experiments combining different cavitation powers and treatment times with different species are required if we are to develop an effective system for suppressing specific algal blooms in particular bodies of water.
\end{abstract}

Key words: cavitation, shock wave, killing of algae, algal biomass

\section{INTRODUCTION}

Phytoplankton thrive in eutrophic waters and decrease their economic value ${ }^{1)}$. Reduction of nutrient loading is the best way to reduce algal biomass, but it is expensive and takes years for results to be achieved. For example, the case of Annadotter et al. ${ }^{2}$ took 17 years. Most prevailing methods to control algal biomass in large scale is artificial mixing by aeration $^{3-11)}$. These methods also require several months to get some reduction of algae.

Several methods have therefore been proposed and developed in attempts to find short-term solutions which will suppress, eliminate, reduce and/or prevent phytoplankton blooms. However, there are several problems to the application of all these methods in situ.. For example, use of a chemical algicide to reduce Microcystis bloom, lime-alum ${ }^{12)}$ caused a sharp rise in $\mathrm{pH}$ and increase in dissolved microcystin and phosphorus concentration in the surrounding water. The effectiveness of suggested biological control agents such as virus ${ }^{13)}$, bacteria $^{14,15)}$, fungi ${ }^{16)}$, actinomycetes ${ }^{17)}$ and protozoa $^{18)}$, in the lake environment depends on a range of biological and physico-chemical factors ${ }^{19)}$.

For example, for virus application, high degree of host specificity, a rapid appearance of resistant host mutants, producing a large amount of active inoculum all become difficulties in practical use. As a physical treatment, UV exposure ${ }^{20)}$ has potential doubt to induce a injure to DNA of exposed organisms, magnetic treatment ${ }^{21)}$ might give algal adaptation to magnetic field in repeated treatment.

Methods of algal control must, in practice, be easy to use, and possible to eliminate or kill the targeted algal bloom in a short time, make it be applicable to a wide variety of phytoplankton species, cause no secondary blooms and be cheap to run.

\footnotetext{
* Corresponding Author
} 
Cavitation was thought to be an innovative means of killing algal cells in pond water and a suitable short term solution to reducing the phytoplankton biomass. The purpose of this study is to make a preliminary evaluation of the effect of cavitation treatment, applied at various power levels to different phytoplankton species, in order to develop the method and assess the extent to which it satisfies the conditions listed above, because no report on the use of cavitation treatment to kill plankton is known.

\section{MATERIALS AND METHODS}

Cavitation The structure of a cavitation system (patent number; 1922580, Apr. 7, $1995)$ is shown in Fig. 1-a. Pond water was pumped into a cylinder $(200 \mathrm{~mm}$ in diameter and $800 \mathrm{~mm}$ long) made of stainless steel (SUS 304) which had a shaft installed inside. The shaft has six wide blades $(12 \mathrm{~cm})$ next to six narrow blades $(7 \mathrm{~cm})$. The narrow and wide blades are oppositely angled (Fig. 1-b) which, when it rotates, easily create drag on the water and thus produce pockets of low density water resulting in air bubbles near the blades. The small air bubbles leave the blades, disperse in the cylinder and then burst, producing ultrasonic shock waves (Fig. 1-c). It is these ultrasonic waves and low density of water around the cells inside bubbles which kill the algal cells.

Samples treated The water was sampled at Hataderaike Pond in Matsuyama, Ehime Prefecture, Japan, on the 1st of November, and at Ogoshiike Pond in Sakaide, Kagawa Prefecture, Japan, on the 6th of December, 1996. The pond water sampled was transferred into a experimental container ( $2 \mathrm{~m}$ long, $2 \mathrm{~m}$ wide, and $1 \mathrm{~m}$ deep). The first pond contained mainly Euglena sp., Peridinium sp., Scenedesmus sp.1, Pediastrum sp.1, and Staurastrum sp.1. The second pond contained, Pediastrum duplex, Scenedesmus sp. 2, Pediastrum sp. 2, and Staurasturum sp. 2.

The pond waters in a container were treated with the cavitation method for one minute each at $360 \mathrm{rpm}$ (P1), $720 \mathrm{rpm}$ (P2), $1000 \mathrm{rpm}$ (P3), $1440 \mathrm{rpm}$ (P4) and $1800 \mathrm{rpm}$ (P5) of the shaft rotation. The retention time of the pond water in the cylinder at each power level was one minute. A method of measuring the shocks generated by the rotation of the shaft, which might be measured as sound pressures, is now under development.

Enumeration of algal cells Phytoplankton cells of the pond water in a container were counted immediately under a microscope without fixation after the cavitation treatment. The triplicate phytoplankton counting was carried out. A count for the pond water in a container without cavitation treatment was used as a control (C). The effectiveness of each cavitation treatment for killing cells was evaluated using the ratio of the number of cells in the pond water after cavitation to those in the control. In order to evaluate the delayed effects of cavitation treatment on the survival of phytoplankton cells, $200 \mathrm{ml}$ of the pond water in a container with and without cavitation treatment were transferred into triplicate $300 \mathrm{ml}$ Erlenmeyer flasks and incubated at $25^{\circ} \mathrm{C}$ under a light intensity of 48.8 to $58.6 \mu$ Einst. $\mathrm{m}^{-2} \mathrm{~s}^{-1}$ with a $12-12$ hours light/dark photo-cycle for 15-20 days. The numbers of cells were counted every other day under the microscope using a haemocytometer.

\section{RESULTS AND DISCUSSION}

Immediate effect The ratios of the numbers of cells observed after cavitation treatment to the number before cavitation treatment are shown in Fig. 2. The immediate effect of cavitation, for example, on Hataderaike Pond water was that about 25 to $50 \%$ of Peridinium sp. died at speeds P1 to P4 but about $75 \%$ at the highest speed P5. The effectiveness of cavitation for causing algal death varied with different species at the different speed of the shaft rotation; Pediastrum sp.1, Staurastrum sp.2, Pediastrum duplex, Peridinium sp., Scenedesmus sp.1, Euglena sp., Pediastrum sp. 2, Scenedesmus sp. 2, and Staurasturum sp. 1 were more susceptible to cavitation at $\mathrm{P} 1$ in that order. It is conceivable that both low density of water in the bubbles and ultrasonic wave produced when the bubbles bursted induced algal disruption. We do not know exactly how alga were damaged 


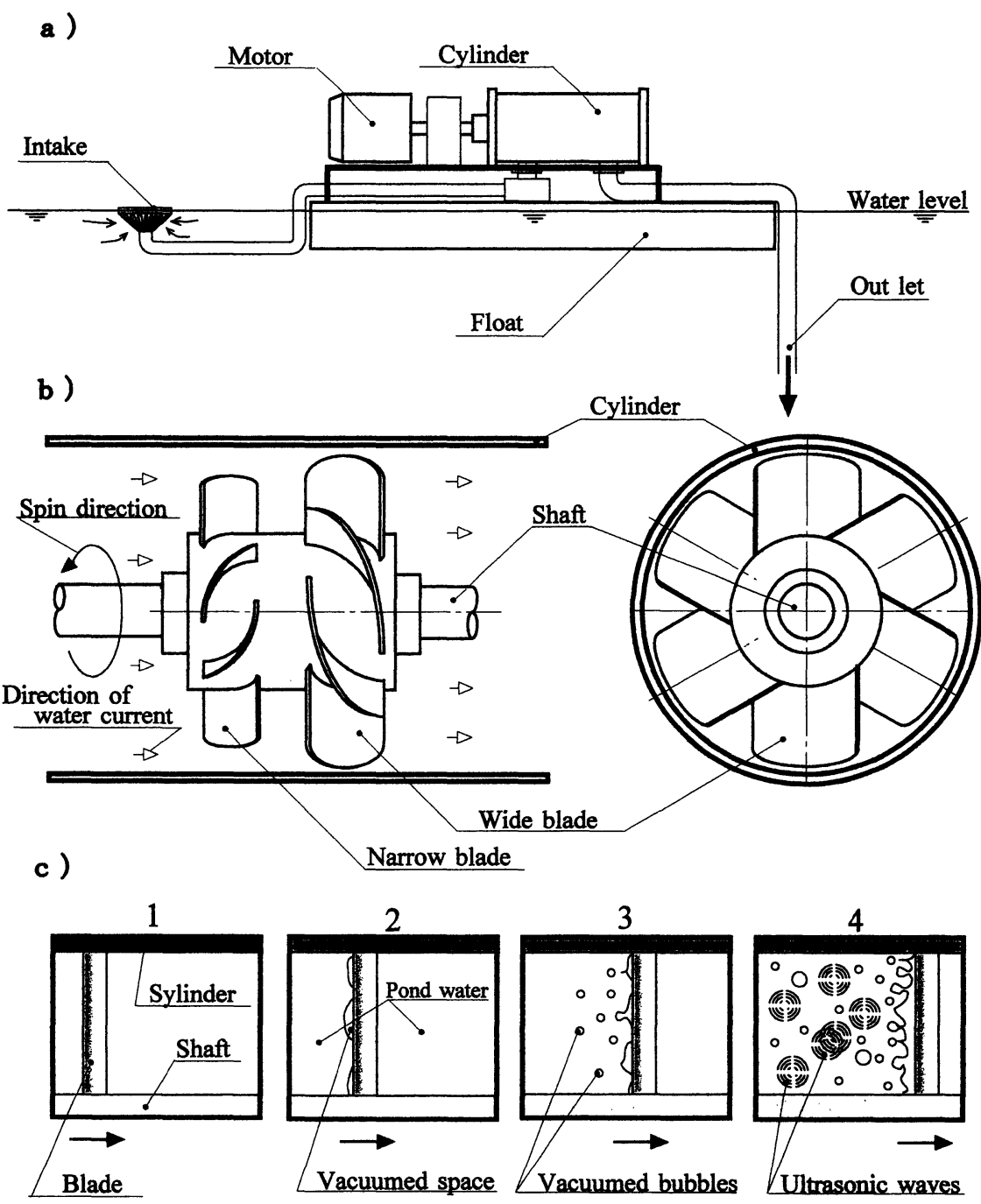

Fig. 1 Schematic illustration of the cavitation system; a) a cross section of the cavitation system, b) the inside structure of the cylinder, and c) generation of the bubbles and ultrasonic waves. Arrows indicate the direction of movement of the blade. The numbers indicate the steps of the cavitation treatment

mechanically by cavitation because of no detail analyses of data on morphological and cytological changes. Under the microscopical observation, debris like particle were observed in the sample treated with cavitation. It is interesting that the same is not true of the second species in each of these genera Scenedesmus, Pediastrum, Staurasturum. This may be due to the different size of coenobium and physiological state in different season among these species. These morphological and physiological differences in these species might receive different degrees of physical damage by caviration. Therefore, the success of this method would be very dependent on which and when species was the target. In all other species the higher speeds (P4-P5) killed a greater proportion of the population than did slower speeds, suggesting that the higher speeds would be needed for any practical application of this method.

It seemed that algae with a cell wall consisting of several plates, such as 
Hataderaike Pond
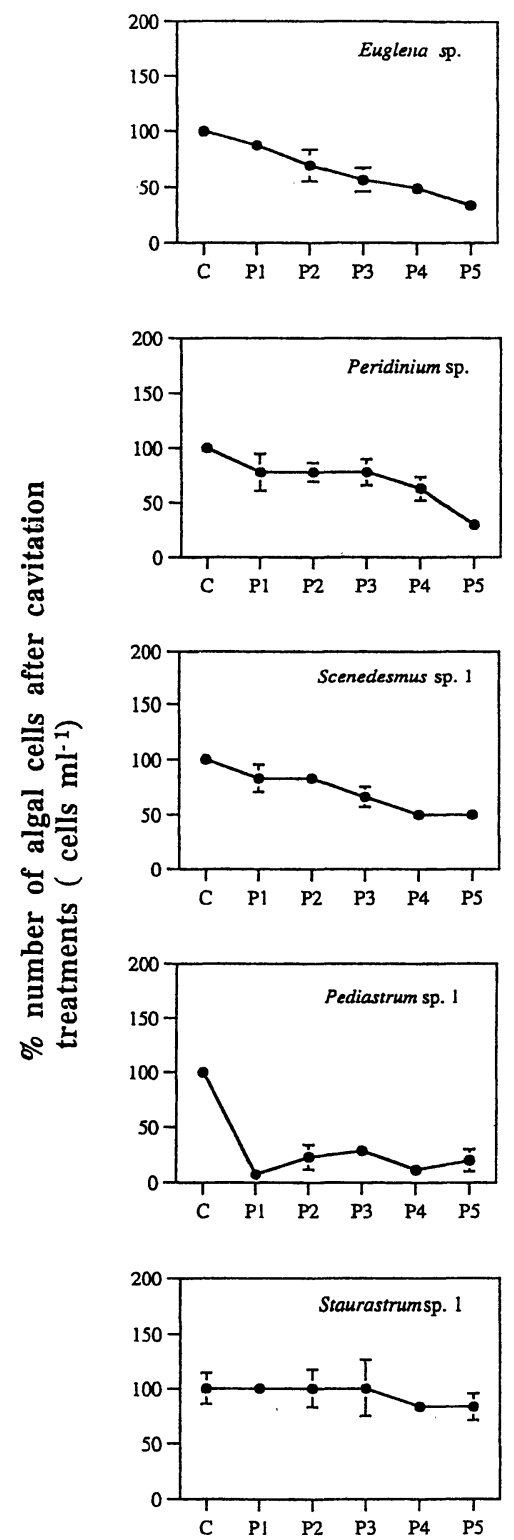

\section{Ogoshiike Pond}
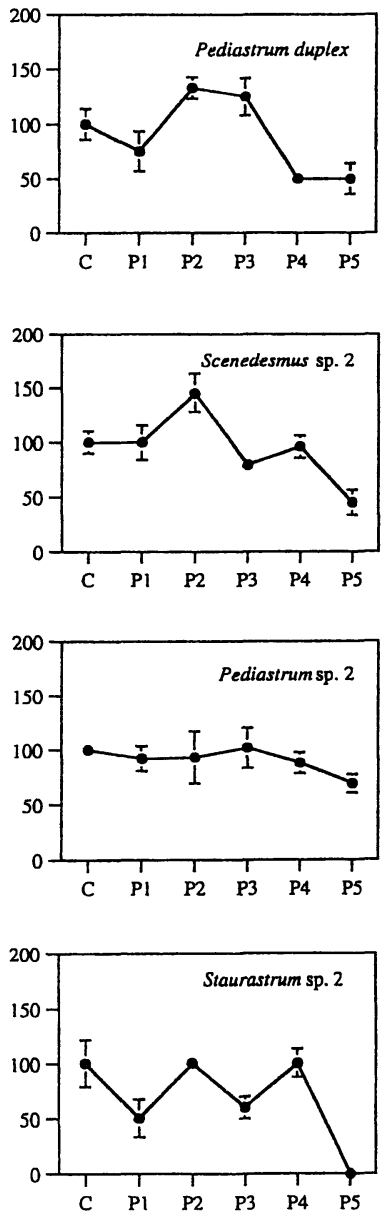

Cavitation treatments (rpm)

Fig. 2 Ratio of the number of cells of each species in the pond waters, Hataderaike Pond and Ogoshike Pond, with to without cavitation treatment (C, P1, P2, P3, P4, P5). Vertical bars represent standard deviations

Peridinium sp., with flagella, such as Euglena sp. and with aggregated multiple unicells, such as Pediastrum were easily killed by the cavitation treatment but that other species were less susceptible.

Delayed effect The growth of algae in the waters from both ponds after cavitation treatment are shown in Fig. 3. The number of cells of each phytoplankton species decreased with time except Scenedesmus sp.1, Pediastrum sp.1 and Staurastrum sp.1 of Hataderaike Pond. Although the algae in the 
Hataderaike Pond
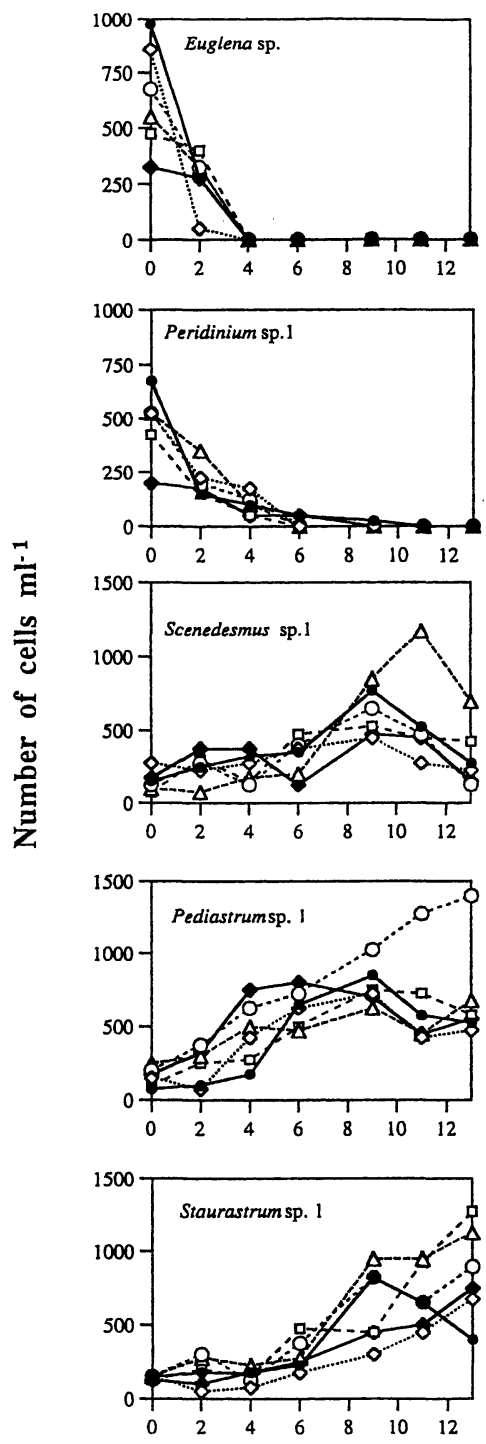

Ogoshiike Pond
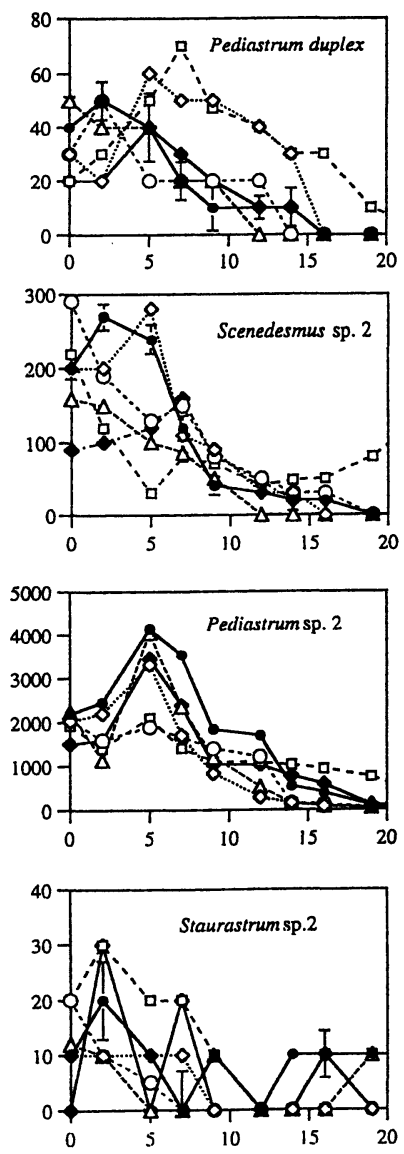

Incubation Time (days)

Fig. 3 Changes in the cell densities of each species of both Hataderaike Pond and Ogoshiike Pond after cavitation treatment $(\mathrm{O} ; \mathrm{C}, \diamond ; \mathrm{P} 1, \bigcirc ; \mathrm{P} 2, \triangle ; \mathrm{P} 3, \square ; \mathrm{P} 4, \diamond ; \mathrm{P} 5)$. Vertical bars represent standard deviations

control also decreased, fewer algal cells were observed in almost the cavitation treatment than in the control for Scenedesmus sp.2 and Pediastrum sp.2 of Ogoshiike Pond. In the case of Scenedesmus sp.1 at P3, Pediastrum sp.1 at P2, Staurastrum sp.1 at all cavitation treatments, and Pediastrum duplex at P3 and $\mathrm{P} 4$, the cell numbers increased more than those of the control. This means that delayed cavitation effect on the algal growth was different depending on the algal species and the shaft rotation speed. 
The biomass reduction was accompanied by discolouration and necrosis. In the cases of Euglena sp. and Peridinium sp., the algae sank to the bottom of the experimental flasks after only 2 days in all treatments but it was 5 days for Pediastrum duplex, Pediastrum sp. 1 and sp. 2, Scenedesmus sp. 1 and sp. 2. The susceptibility of algae to cavitation treatment, as observed in the immediate effect, was easy to see as they sank to the bottom of the flask. These settled algae did not refloat throughout the period of the experiment, suggesting that the cavitation treatment caused some physical damage resulting in loss of their ability to move up into the favorable surface water to grow. Thus, the cavitation may also have a delayed effect on the growth of some algae. On the other hand, cavitation treatment in the field would accelerate the deposition of alga on to the bottom sediment and change the oxygen regime at the bottom, depending on the magnitude of organic loading ${ }^{22}$.

The released organic matter would might enhance the bacterial growth subsequently increasing the biomass of heterotrophic nanoflagellates, ciliates and rotifers, which prey on picophytoplankton ${ }^{23)}$ and crustaceans which prey on nanophytoplankton through the microbial loop. The predation of zooplankton on pico- and nano- phytoplankton might favors the the growth of large size phytoplankton. Thus, the possibility of another subsequent algal bloom would not be denied depending on the food web structure of the pond ${ }^{24)}$.

It was also likely that the leakage of nutrients into the pond water from the damaged cells stimulated the growth of the cells that are not damaged by the treatment. This appears to be the case for Scenedesmus sp.1, Pediastrum sp.1, and Staurastrum sp.1(Fig.3).

It was assumed in the case of toxic alga that cavitation might released toxic substances from toxic cyanobacteria ${ }^{1,25-27)}$, subsequently causing the growth inhibition of zooplankton $^{28}$. This is not always the case, because bacteria might decompose toxic substances in cooperation with micro animals $^{29)}$.

Algal blooms which have harmful effect on animals, and potentially on human beings are cyanobacterial blooms, especially Microcystis blooms ${ }^{1,27,30,31)}$. In cyanobacteria the gas-vesicles would be among the most sensitive structures to cavitation disenabling the use of buoyancy that is essential in cyanobacterium formation. This aspect would merit attention, especially form an applied point of view. Cyanobacterial blooms are formed in the upper layer of epilimnion. Therefore, for cyanobacteria, cavitation treatment is not need for the whole lake water but only for surface water. This might enable cavitation treatment efficiently applicable to the cyanobacterial blooms.

These results show a strong possibility of the effectiveness of cavitation treatment to immediately suppress algal densities in lakes and ponds. However, in order to develop an effective cavitation treatment, it is necessary to conduct the experiments under various combinations of cavitation power, time of treatment, different species and their physiological condition. Other than this point, to evaluate whether or not cavitation treatment is a realistic method for the suppression of algal blooms, the possibility of secondary effects mentioned above, such as sedimentation of damaged cells, released organic matter from damaged cells, release of toxic substances from damaged toxic algae, enhancement of microbial loop, and another subsequent algal bloom, must be considered, as must the expense of running such treatment.

\section{ACKNOWLEDGMENT}

We thank Prof. T. Fukushima of Department of Rural Engineering, Ehime University for his permission to use his laboratory equipment.

\section{REFFERENCE}

1) Falconer I. R.: Potential impact on human health of toxic cyanobacteria, Phycologia, 35 (6 Suppl), 6-11 (1996)

2 ) Annadotter H., Cronberg G., Aagren R., Lundstedt B., Nilsson P. A., and Strobeck S.: Multiple techniques for lake retoration, Hydrobiol., 395-396, 77-85 (1999) 
3 ) Toetz D. W.: Biological and water quality effects of artificial mixing of Arbuckle Lake, Oklahoma, during 1977, Hydrobiol., 63(3), 255-262 (1979)

4 ) Reynolds C. S., Wiseman S. W., and Clarke M. J. O.: Growth- and loss- rate responses of phytoplankton to intermittent artificial mixing and their potential application to the control of planktonic algal biomass, J. Appl. Ecol., 21, 11-39 (1984)

5 ) Mcqueen D. J. and Story V. A.: Impact of hypolimnetic aeration on zooplankton and phytoplankton populations, Environmental Technology Letters, 7(1), 31-41 (1986)

6 ) Cowell B. C., Dawes C. J., Gardiner W. E., and Scheda S. M.: The influence of whole lake aeration on the limnology of a hypereutrophic lake in central Florida. Hydrobiol., 148, 3-24 (1987)

7 ) Reynolds C. S.: The long, the short and the stalled: on the attributes of phytoplankton selected by physical mixing in lakes and rivers, Hydrobiol., 289, 9-21 (1994)

8 ) Visser P. M., Ketelaars H. A. M., and Mur L. R.: Reduced growth of the cyanobacterium Microcystis in an artificially mixed lake and reservoir, Wat. Sci. Tech., 32(4), 53-54. (1995)

9 ) Visser P. M., Ibelings B. W., Veer B. V. D., Koedood J., and Mur L. R.: Artificial mixing prevents nuisance blooms of the cyanobacterium Microcystis in Lake Nieuwe Meer, the Netherlands, Freshwater Biol., 36 , 435-450 (1996)

10) Lilndenschmidt K. E.: Controlling the growth of Microcystis using surged artificial aeration, Internat. Rev. Hydrobiol., 84(3), 243-254 (1999)

11) Imteaz M. A. and Asaeda T.: Artificial mixing of lake water by babble plume and effects of bubbling operations on algal bloom. Wat. Res., 34(6),1919-1929 (2000)

12) Lam A. K.-Y. and Prepas E. E.: In situ evaluation of options for chemical treatment of hepatotoxic cyanobacterial blooms, Can. J. Fish. Aquat. Sci., 54(8), 1736-1742 (1997)

13) Safferman R. S. and Morris M. E.:
Evaluation of natural products for algicidal properties, Appl. Microbiol. 10, 289-292 (1962)

14) Daft M. J. and Stewart W. D. P.: Bacterial pathogens of freshwater blue green algae, New Phytol., 70, 819-829 (1971)

15) Manage P. M., Kawabata $Z$., and Nakano S.: Algicidal effect of the bacterium Alcaligenes denitrificans on Microcystis spp., Aquat. Microb. Ecol., 22(2), 111-117 (2000)

16) Daft M. J., Burnham J. C., and Yamamoto Y.: Algal blooms: consequences and potential cures, J. appl. Bact., 175S186S (1985)

17) Safferman R. S. and Morris M. E.: Control of algae with viruses, J. Amer. Wat. Works Assoc., 56, 1217-1224 (1964)

18) Sugiura N., Inamori Y., Ouchiyama T., and Sudo R.: Degradation of cyanobacteria, Microcystis by microflagelate, Monas guttula, Wat. Sci. Tech., 26, 2173-2176 (1992)

19) Sigee D. C., Glenn R., Andrews M. J., Bellinger E. G., Butlter R. D., Epton H. A. S., and Hendry R. D.: Biological control of cyanobacteria: principles and possibilities, Hydrobiol., 395/396, 161-172 (1999)

20) Iseri Y., Kawabata Z., and Sasaki M.: Development of a boat equipped with UV lamps for suppression of freshwater red tide in a reservoir, Jap. J. Water Treat. Biol., 29, 61-70 (1993)

21) Newman J. R. and Watson R. C.: Preliminary observations on the control of algal growth by magnetic treatment of water, Hydrobiol., 415, 319-322 (1999)

22) Hansen L. S. and Blackburn T. H.: The effect of algal bloom deposition on sediment respiration and fluxes. Marine Biology (Berlin), 112(1), 147-152 (1992)

23) Weisse T.: Dynamics of autotrophic picoplankton in Lake Constance, $J$. Plankton Res., 10, 1179-1188 (1988)

24) Sommer U.: Phytoplankton succession in microcosm experiments under simultaneous grazing pressure and resource limitation. Limnol. Oceanogr., 33, 1037-1054 (1988)

25) Watanabe F. M. and Oishi S.: Toxic substance from a natural bloom of 
Microcystis aeruginosa, Appl. Environ. Microbiol., 43(4), 819-822 (1982)

26) Sivonen K., Niemela S. I., Niemi R. M., Lepisto L., Luoma T. H., and Rasanen L. A.: Toxic cyanobacteria (blue-green algae) in Finnish fresh and coastal waters, Hydrobiol., 190(3), 267-275 (1990)

27) Matsunaga H., Harada K. I., Senma M., Ito Y., Yasuda N., Ushida S., and Kimura I.: Possible cause of unnatural mass death of wild birds in a pond in Nishinomiya, Japan:Sudden appearance of toxic cyanobacteria, Natural Toxins 7(2), 8184 (1999)

28) Lampert W.: Further studies on the inhibitory effect of the toxic blue-green Microcystis aeruginosa on the filtering rate of zooplankton, Arch. Hydrobiol., 95, 207-220 (1982)
29) Inamori Y., Sugiura N., Iwami N., Matsumura M., Hiroki M., and Watanabe M. M.: Degradation of the toxic cyanobacterium Microcystis viridis using predaceous micro-animals combined with bacteria, Phycol. Res., 46, 37-44 (1998)

30) Torbjorn W. and Roland M.: Waterblooming and toxin-producing cyanobacteria in Swedish fresh and brackish waters, 1918-1995. Hydrobiol., 353, 181-192 (1997)

31) Song L., Sano T., Li R., Watanabe M. M., Liu Y., and Kaya K.: Microcystin production of Microcystis viridis (Cyanobacteria) under different culture conditions, Jap. J. Phycol., 46, 19-23 (1998)

(Submitted 2002. 3. 8) (Accepted 2002. 6. 24) 